\title{
Memórias docentes da literatura de autoria feminina no contexto de experiências em
}

\section{um curso de Letras}

\author{
Faculty memories of female authorship literature in the constext of experiences in a Literature
}

course

Memorias de la facultad de literatura de autoría femenina em el contesto de experiencias em um curso de Literatura

Recebido: 12/06/2021 | Revisado: 16/06/2021 | Aceito: 16/06/2021 | Publicado: 29/06/2021

\author{
Leoniza Saraiva Santana \\ ORCID: https://orcid.org/0000-0001-6619-6219 \\ Universidade Federal do Amazonas, Brasil \\ E-mail: Leoniza.saraiva21@gmail.com \\ Maria Isabel Alonso Alves \\ ORCID: https://orcid.org/0000-0002-2960-1200 \\ Universidade Federal do Amazonas, Brasil \\ E-mail: profamariaisabel@ufam.edu.br
}

\begin{abstract}
Resumo
As mulheres há muito tempo vêm lutando por seu espaço em vários setores da sociedade que ainda é sexista. Um desses espaços é o direito de escrever, publicar e ser reconhecida por seus escritos. Assim, este estudo tem por objetivo averiguar se na memória narrativa dos/das docentes egressos e formadores do Curso de Letras do IEAAUFAM de Humaitá-Amazonas, Brasil, há a presença da Literatura de Autoria Feminina e saber se as memórias narradas refletem, de alguma forma, em suas práticas pedagógicas no ensino de Literatura, Linguagem e Língua Portuguesa. O estudo tem uma abordagem qualitativa e os procedimentos metodológicos utilizados têm por base os estudos pós-críticos de pesquisa em educação, com foco nas entrevistas narrativas. O estudo traz alguns pontos da história da Literatura de Autoria Feminina no Brasil, bem como as memórias narrativas dos/das docentes que apontam quando a LAF começou a fazer parte da vida de cada um/uma, a formação da identidade feminina a partir das identificações com os escritos das autoras, a análise das memórias docentes da LAF e como elas ainda influenciam esses profissionais em sua práxis docente. Como resultados o estudo aponta que os docentes tem memória da LAF e estas influenciam em seus trabalhos com os discentes em suas salas de aula.
\end{abstract}

Palavras-chave: Memória docente; Literatura de autoria feminina; Identidade feminina; Ensino; Formação docente.

\begin{abstract}
Women have long been fighting for their space in various sectors of society that are still sexista. One of these spaces is the right to write, publish and be recognizes for their writings. Thus, this study aims to investigate whether in the narrative memory of the graduate teachers and trainers of the Literature Course at the IEAA-UFAM in HumaitáAmazonas, Brazil, there is the presence of Literature of Female Authorship and to know if the memories narrated reflect, somehow, in their pedagogical practices in the teaching of Literature, Language and Portuguese Language. The study has a qualitative approach and the methodological procedures used are based on post-critical studies of research in education, with a focus on narrative interviews. The study brings some points in the history of Female Authorship Literature in Brazil, as well as the narrative memories of the teachers that point out when the LAF began to be part of each person's life, the formation of the female identity based on the identifications with autrhors' writings, the analysis of the professors' mememories of the LAF and how they still influence these professional in their teaching práxis. As a result, the study points out that teachers have memory of the LAF and these influence their work with in their classroms.
\end{abstract}

Keywords: Teacher memory; Female authorship literature; Female identity; Teaching; Teacher training.

\section{Resumen}

Las mujers llevan mucho tempo luchando por su espacio em diversos sectores de la sociedade que aún son sexistas. Uno de estos espacios es el derecho a escribir, publicar y ser reconocido por sus escritos. Así, este estúdio tiene como objetivo indagar si em la memoria narrativa de los egresados profesores y formadores del Curso de Literatura en el IEAA-UFAM de Humaitá-Amazonas, Brasil, existe la presencia de Literatura de Autoría Femenina y saber si los recuerdos narrados se reflejan, de alguna manera, em sus prácticas pedagógicas en la enseñanza de la Literatura, la Lengua y la Lengua Portuguesa. El estúdio tiene um enfoque cualitativo y los procedimentos metodológicos utilizados 
se basan en studios poscríticos de investigación en educación, com enfoque en entrevistas narrativas. El estúdio trae algunos puntos de la historia de la Literatura de Autoría Femenina en Brasil, así como las memorias narrativas de las maestras que señalan cuando la LAF comenzó a ser parte de la vida de cada persona, la formación de la identidade feminina a partir de las identificaciones com el escritos de los autores, el análisis de la memoria de los profesores sobre las LAF y como aún influyen em estos profesionales em su práxis docente. Como resultado, el estúdio señala que los profesores tienen memoria de las LAF y estas influyen en su trabajo com los estudiantes em sus aulas.

Palabras clave: Memoria del maestro; Literatura de autoría feminina; Identidad femenina; Enseñando; Formación de profesores.

\section{Introdução}

A Literatura permite a construção de sentidos propostos por diversos tipos de textos que, de acordo com Chartier (1997, p. 68) “Uma história da literatura é então uma história das diferentes modalidades de apropriação dos textos. Ela deve considerar que o 'mundo do texto', usando as palavras de Ricoeur, é um mundo de 'performances' cujos dispositivos e regras possibilitam e restringem a produção do sentido.” E é a Literatura que mexe com a memória de quem a escreve ou a lê. Memória esta que fica armazenada para retornar no momento que lhe é solicitada a presença, mas que às vezes a resistência ou bloqueios aprisionam qualquer retorno de uma leitura que marcou significativamente quem a leu. Assim, as memórias de alguns travam e não há a identificação com autores, temáticas, obras, estilos, etc.

Destaque-se que "A memória é a capacidade humana de reter fatos e experiências do passado e retransmiti-los às novas gerações através de diferentes suportes empíricos (voz, música, imagem, textos, etc)” (Simson, 2003, p. 14). E assim, a memória humana é uma grande caixa repleta de informações/lembranças que muitas vezes não são acessadas porque a pessoa acredita que já não lembra mais ou nunca guardou tal referência como afirma Halbwachs (2013, p. 105) “[...] cada fato encontra-se separado do que o procede ou o segue por um intervalo, em que se pode acreditar que nada aconteceu”. Na realidade está tudo imerso na mente humana que é mais poderosa do que alguns imaginam. É nela que estão muitas respostas para identificações ou não que se tem, por exemplo, com a Literatura de Autoria Feminina (LAF).

Tal preocupação surge porque há ainda a marginalização com os escritos das autoras e destaque da intelectualidade masculina em detrimento da feminina. Desta forma, muitas mulheres, de diversos cursos de Licenciatura, ainda não têm esse contato identitário durante o processo de formação inicial docente. E, para este estudo, selecionamos o Curso de Letras ${ }^{1}$ do Instituto de Educação, Agricultura e Ambiente (IEAA)² campus da Universidade Federal do Amazonas (UFAM) em Humaitá$\mathrm{AM}^{3}$, porque queríamos averiguar, mais de perto, as memórias dos docentes egressos deste Curso que estão atuando no município e adjacências. E também as memórias dos professores formadores deste Curso que trabalham com as disciplinas de Literatura, Linguagens e Língua Portuguesa. Então, para este primeiro momento o Curso de Letras foi o escolhido.

Algumas das perguntas que nortearam este estudo foram: Como se deu historicamente o "levantar de vozes" das mulheres brasileiras para que fossem visibilizadas em sua escrita literária? Os professores do Curso de Letras do IEAAUFAM, que ministram as disciplinas de Literatura, Linguagens, Língua Portuguesa, possuem memórias da LAF? E os egressos

\footnotetext{
1 Curso com dupla licenciatura: Português e Inglês, extensivo às literaturas de expressão em ambas as línguas. Criado pela resolução 030/05-CONSUNIUFAM, de 25 de novembro de 2006, o Curso de Letras iniciou suas atividades letivas no segundo semestre de 2006 (IEAA-UFAM, 2016, p. 45) que assim ficou instituído e regido por seu Projeto Pedagógico de Curso de 2006/2.

2 O IEAA foi criado em 04/10/2006, pela Portaria do Conselho Universitário - CONSUNI 028/2005, no município de Humaitá. Em 03/08/2009, a Portaria de nº 011/2009 do Conselho de Administração (CONSAD) alterou o nome para Instituto de Educação, Agricultura e Ambiente. Os cursos de graduação presentes são: Agronomia, Ciências: Biologia e Química, Ciências: Matemática e Física, Engenharia Ambiental, Letras: Literatura e Língua Portuguesa e Inglesa, Pedagogia. Também possui o Programa de Pós-Graduação em Ciências Ambientais - PPGCA e o Programa de Pós-Graduação em Ensino de Ciências e Humanidades - PPGECH. Possui um corpo docente com 81 profissionais, 31 técnicos administrativos, 1.757 discentes de graduação, 65 mestrandos na pósgraduação (IEAA/UFAM, 2016).

${ }^{3}$ A cidade de Humaitá, no Amazonas, possui segundo as estimativas divulgadas pelo IBGE (2020), cinquenta e seis mil, cento e quarenta e quatro (56.144) munícipes. E é um município brasileiro localizado no sul do estado do Amazonas pertencendo à região do Madeira. Ela está a 640 km de Manaus por rodovia, $730 \mathrm{~km}$ por via aérea e $935 \mathrm{~km}$ por via fluvial (Almeida, 2005, p. 107).
} 
que atuam na área da educação também têm essa memória da LAF? Como a LAF está sendo refletida nas práxis desses/as professores e professoras em sala de aula?

A leitura permite a ampliação de mundo de cada ser humano e a identificação com essa leitura propicia a inclusão de pertencimento, de identidade com algo que lhe faz bem. Assim, quando não se tem uma representatividade nos textos trabalhados nas escolas e instituições superiores, é como se o indivíduo não existisse, falta a identidade e essa lacuna (ausência de textos de autoria feminina) pode ter impactado muitas mulheres e, se ainda persistirem poderão travar outras. Por isso que este estudo pretende também trabalhar a temática relacionada à identidade feminina.

A escrita de autoria feminina, tão discriminada anteriormente, traz a voz feminina onde até então ecoavam somente vozes masculinas. Faz-se importante o estudo de gênero dessa literatura para que se detectem os entraves e também as conquistas da prática no ensino superior no que concerne à inclusão das escritoras, das várias épocas da Literatura universal, nos materiais estudados pelos discentes, realização de trabalhos e na dinâmica das aulas dos docentes.

Nesta vertente, o ensino e a aprendizagem incluem em seus processos o pensamento feminino em contrapartida com uma sociedade que, por muito tempo, inferiorizou os sentimentos e a intelectualidade feminina, relegando à mulher um lugar de subalternidade e abafando seu poder de arguição e contestação.

É relevante tal estudo porque tanto na educação básica quanto na educação superior já foram dados passos em relação a este tema da LAF e que devem ser postos para análise, discussão e busca de mais estudos na área visando sempre melhorias. A leitura, interpretação e valorização das vozes femininas trazem uma gama de novidades formais para o meio artístico, literário brasileiro e mundial, pois seus temas têm também importância histórica e política pelas manifestações de vozes outrora silenciadas. Dito de outra forma, as autoras inovaram na escrita e no papel da mulher em sua participação num meio predominantemente masculino.

Assim sendo, tanto a formação quanto a prática pedagógica do/a professor/a de Literatura, Linguagens e Língua Portuguesa vêm apresentar uma variedade de conhecimentos das práticas alcançadas no decorrer de sua vida acadêmica e profissional que servem de apoio nos processos de ensino e de aprendizagem dos estudantes. Não deixando de valorizar a realidade que cerca aos discentes e a identidade impregnada em cada um que se identifica ou se sente representado com os escritos das autoras.

Pretendemos com este trabalho averiguar se na memória narrativa dos/das docentes, que cederam as entrevistas, há a presença da Literatura de Autoria Feminina e saber se as memórias narradas refletem, de alguma forma, em suas práticas pedagógicas no ensino de Literatura, Linguagem e Língua Portuguesa. Por isso, este estudo vem revestido de relevância nos âmbitos acadêmico, científico e social porque abrange um mundo que está além das salas de aula e das fronteiras territoriais, pois vem buscar respostas/pistas/propostas para aquelas perguntas que viram grandes obstáculos na inclusão da voz feminina em meio ao cânone masculino e nas aulas de Literatura, Linguagens e Língua Portuguesa tanto no ensino básico como no ensino superior.

\section{Metodologia}

O caminho a ser percorrido por esta pesquisa é pensado a partir do entendimento de que não há certezas absolutas no fazer pesquisa (Costa, 2007), tendo em vista que só se tem a "certeza" dos passos, espaços, terreno, sujeitos quando você se põe para caminhar, ou seja, acontece o conhecimento real dos fatos a partir do momento que existe o contato direto com o que você está pesquisando. Nesta mesma direção, Meyer e Paraíso (2012, p. 15) afirmam que "uma metodologia de pesquisa é sempre pedagógica porque se refere a um como fazer, como fazemos ou como faço minha pesquisa". Assim, o percurso metodológico desta pesquisa é exposto da seguinte forma: inicialmente, apresenta-se o método escolhido e, em seguida as técnicas utilizadas no estudo ora apresentado. 
Esta pesquisa está estruturada no campo dos Estudos Pós-Críticos e em relação a isso Meyer e Paraíso (2012, p. 15) dizem que "sua função pedagógica, no entanto, produz estranhamentos quando adjetivamos essas metodologias de pesquisas como 'pós-críticas'. Afinal, a maior parte das correntes teóricas denominadas pós-críticas não se referem a um método de pesquisa, no sentido usual do termo". É importante a fala de Meyer e Paraíso (2012) porque há uma preocupação em explicar com relação ao campo teórico escolhido para embasar esta pesquisa.

Desta forma Meyer e Paraíso (2012, p. 116) definem metodologia pós-crítica argumentando

[...] 'metodologia' é um termo tomado em nossas pesquisas de modo bem mais livre do que o sentido moderno atribuído ao termo 'método'. Entendemos metodologia como um certo modo de perguntar, de interrogar, de formular questões e de construir problemas de pesquisa que é articulado a um conjunto de procedimentos de coleta de informações - que, em congruência com a própria teorização, preferimos chamar de 'produção' de informação - e de estratégias de descrição e análise.

As autoras expõem o quanto o campo pós-crítico é combativo as rigidezes buscando para isso que suas pesquisas sejam mais claras e compreensíveis. No mesmo sentido, Veiga Neto (2003, p. 20) também aponta que "O sentido que damos ao termo 'método' em nossas pesquisas, portanto, está bem mais próximo ao sentido que the dava a escolástica medieval: algo como um conjunto de procedimentos de investigação e análises quase prazerosos, sem maiores preocupações com regras". E Larrosa (2011, p. 37) acrescenta que "Compreendemos o método, em síntese, como uma certa forma de interrogação e um conjunto de estratégias analíticas de descrição". O que é percebido nas falas dos autores e autoras é que o campo pós-crítico está construído de modo a movimentar-se sem medo dos erros e acertos desde que se aproxime do objeto e descreva, interrogue e analise-o.

Quanto à abordagem deste estudo optou-se pela qualitativa que conforme González Rey (2005, p. 103): “A pesquisa qualitativa caracteriza-se pela construção de um modelo teórico como via de significação da informação produzida, a qual não está fragmentada em resultados parciais associados aos instrumentos usados, mas está integrada em um sistema cuja inteligibilidade é produzida pelo pesquisador". O pesquisador/a utiliza sua ótica de observação para dá significado ao que o sujeito está mostrando a partir de sua perspectiva de vivência e com isso a abordagem qualitativa auxilia os pesquisadores e pesquisadoras nos mais variados contextos em que o sujeito de sua pesquisa está inserido.

Os procedimentos metodológicos apontados nesta dissertação encontram-se estruturados nos pressupostos pós-críticos em que a "produção do sujeito se dá no âmbito da linguagem, na relação com as forças discursivas que o nomeiam e governam, sendo a escola um desses locais da cultura no qual se produz e se nomeia o sujeito" (Andrade, 2012, p. 174).

Os dados não são coletados, mas produzidos de acordo com o que afirma González Rey (2005, p. 100) "os dados não se coletam, mas se produzem e (...), porque o dado é inseparável do processo de construção teórica no qual adquire legitimidade". Desta forma, foram produzidos a partir de levantamento bibliográfico, documental e de campo os dados deste estudo. Sendo que a pesquisa bibliográfica foi utilizada para fundamentar o estudo com pesquisas realizadas em vários tipos de materiais impressos e digitais.

Também foram consultadas revistas que conversavam com o tema que foi trabalhado na pesquisa, além de utilizar como fonte a Biblioteca Digital Brasileira de Teses e Dissertações (BDTD) juntamente com a Base Digital de Teses e Dissertações da UFAM e o Repositório Institucional da UFAM - RIU. Com relação à pesquisa documental, foram estudados alguns dos documentos que regem o Curso de Letras tendo em vista que a pesquisa foi realizada no âmbito deste curso no IEAA.

A matriz analítica desta pesquisa encontra-se ancorada nos conceitos dos Estudos Culturais situados num contexto Pós-crítico. Neste sentido, cabe mencionar que os dados foram produzidos a partir da entrevista narrativa tendo em vista os apontamentos de Andrade (2012), Costa (2007), Szymanski (2018) e Silveira (2007), que definem a entrevista narrativa como 
algo que não vem pronto ou acabado, mas constrói-se juntamente com o sujeito e por isso mesmo a entrevista narrativa tornase um contato de ir e vir entre a pesquisadora e os/as entrevistados/as.

Os sujeitos desta pesquisa são cinco docentes do Colegiado de Letras do IEAA-UFAM que ministram aulas nas áreas de Literatura, Língua Portuguesa e Linguagem; e oito egressos do curso de Letras do IEAA-UFAM. Destes egressos um está atuando como professor substituto de Língua Portuguesa no Curso de letras do IEAA-UFAM e sete lecionam Literatura, Língua Portuguesa e Língua Inglesa em escolas públicas na sede e área ribeirinha de Humaitá, Manicoré e na cidade de Porto Velho-RO. Quanto aos nomes, todos/as os/as professores/as entrevistados/as foram mantidos/as em sigilo visando manter o anonimato para não sentirem-se de alguma forma constrangidos/as, pois este não é o objetivo da pesquisa.

Assim, foram escolhidos por eles e elas, nomes de mulheres escritoras nacionais e internacionais. Estes sujeitos são os professores/as egressos: Ana Cesar, Clarice Lispector, Carolina de Jesus, Sylvia Plath, Florbela Espanca, Jane Austen, Kate Chopin, Emily Brontë. E estes/as são os professores formadores: Andréa del Fuego, Violeta Branca, Eliane Potiguara, Virginia Woolf, Simone de Beauvoir. Importante destacar que o consentimento foi voluntário e o Termo de Consentimento Livre e Esclarecido foi explicado aos/as entrevistados/as e assinado por todos/todas. Reforça-se que este estudo não tem fins lucrativos e não visa remunerar a nenhum dos/das entrevistados/as.

\section{As Vozes das Mulheres Brasileiras na LAF: Visibilização de uma Escrita Silenciada}

Foram muitas as escritoras que vieram romper com o silêncio outrora imposto a todas aquelas que foram emudecidas por um sistema que não permitia a evolução das mulheres em qualquer área que ousasse sair do recanto "sagrado do lar" que foram introduzidas por séculos a lá estarem e assumirem essa postura de mulher recatada e do lar como natural e a única a que podiam usufruir. Em relação ao desejo da mulher de escrever sobre si mesma, Norma Telles (2009, p. 403) afirma

Tal qual um Deus Pai que criou o mundo e nomeou as coisas, o artista torna-se o progenitor e procriador de seu texto. À mulher é negada a autonomia, a subjetividade necessária à criação. O que lhe cabe é a encarnação mítica dos extremos de alteridade, do misterioso e intransigente outro, confrontado com veneração e temor. O que lhe cabe é uma vida de sacrifícios e servidão, uma vida sem história própria. Demônio ou bruxa, anjo ou fada, ela é mediadora entre o artista e o desconhecido, instruindo-o em degradação ou exalando pureza. É musa ou criatura, nunca criadora.

Conforme se pode constatar a mulher é sempre abnegada do ato de criar, mas mesmo assim desafia a sociedade patriarcalista e começa a escrever sobre tudo que ver como direito seu. Então passa de criatura a criadora de sua própria história, porém a ideologia machista e opressora que ainda afeta mulheres do mundo inteiro, insiste em menosprezá-las e de acordo com Malvina Muszkat (1985, p. 13)

Mulheres de todos os tipos, tendo reconhecido a desigualdade de suas condições na cultura, se dispuseram, conscientemente, a lançar-se numa luta de liberação psicológica e social, questionando padrões antigos. O surgimento e uma espécie de irmandade estimula um número cada vez maior de mulheres a saírem em busca de novas maneiras de se conduzir existencialmente (grifo da autora).

Isso que Muszkat (1985) veio falando em seus escritos é a base da revolução feminista que lutou com todas as suas forças para que as mulheres fossem ouvidas de alguma forma. Todos os "tipos" de mulheres como realça a autora, mulheres que desejavam ardentemente a sua libertação e de todas as outras que nem sabiam que eram presas por este sistema sexista. E mesmo com todo um sistema machista ao seu redor, ditando regras de um modo geral e delimitando o espaço feminino, a mulher lutou para ser criadora de si mesma, de suas vontades e desejos outrora reprimidos. Então inicia sua escrita no século XVIII conforme Norma Telles (2009, p. 403) confirma: 
[...] foi a partir dessa época que um grande número de mulheres começou a escrever e publicar, tanto na Europa quanto nas Américas. Tiveram primeiro de aceder à palavra escrita, difícil numa época em que se valorizava a erudição, mas lhes era negada educação superior, ou mesmo qualquer educação a não ser a das prendas domésticas; tiveram de ler o que sobre elas se escreveu, tanto nos romances quanto nos livros de moral, etiqueta ou catecismo. A seguir, de um modo ou de outro, tiveram de rever o que se dizia e rever a própria realização. Tudo isso tornava difícil a formulação do eu, necessária e anterior à expressão ficcional.

A mulher revela-se escritora, mostra a ótica feminina também em suas obras. E, com isso, surgem alguns manifestos femininos que, após a independência do Brasil, apoiaram não só a emancipação política do país, mas a inclusão das mulheres nos direitos que thes foram usurpados desde sempre. Percebe-se aqui que as brasileiras, no mínimo, leram as ideias difundidas na Europa do século XVIII que versavam "sobre a posição da mulher na sociedade e suas reivindicações de igualdade" (Telles, 2009, p. 405). Assim, no Brasil, a escritora inglesa Mary Wollstonecraft teve suas ideias também difundidas por Nísia Floresta (2009, p. 405).

Desta forma revelaram-se as escritoras no Brasil. Mulheres como "Nísia Floresta Brasileira Augusta era o pseudônimo adotado por Dionísia de Farias Rocha, nascida num pequeno sítio de propriedade dos pais em Papari no Rio Grande do Norte, localidade que hoje recebeu seu nome" (Telles, 2009, p. 405). Revelaram-se outras escritoras como Maria Firmina dos Reis (1825-1917), Maria Benedicta Camara Bormann (1853-1895) e Júlia Lopes de Almeida (1862-1934) que escreveram sobre várias temáticas que envolviam a escravidão, o feminismo da época e seus anseios.

Essas vozes femininas, segundo Zolin (2003, p. 165) "romperam o silêncio e publicaram textos de alto valor literário, denunciadores da opressão da mulher, embora a crítica não os tenha reconhecido na época". Isso demonstra que eram desbravadoras em busca de seus sonhos e abrindo espaços para as outras que viriam também. Falci (2009, p. 253) acrescenta que "Outras mulheres, contrariando as expectativas sociais, tornaram-se poetisas". Dentre essas se identificou Narcisa Amália dos Campos (1852-1924), Cora Coralina (1889-1985), Gilka Machado (1893-1980), Cecília Meireles (1901-1964), Violeta Branca (1915-2000), para citar algumas das poetas brasileiras que também foram as pioneiras na arte da escrita no Brasil. Escrita esta feita por aquelas que lutaram para serem valorizadas em uma sociedade que as excluíam.

\subsection{Identidade Feminina}

Por mais que alguns neguem ou escondam esse desejo, o ser humano necessita de identificação para que se torne real sua existência, individualidade, peculiaridades que os diferem dos demais ou que os assemelhem aos grupos que admiram, desejam imitar ou seguir. Homens e mulheres anseiam por essa identificação e valorização. E é por isso que se faz importante o estudo da Identidade Feminina, saber se existe uma identidade só das mulheres ou como isso acontece, o que é ser mulher numa sociedade com múltiplas identidades. Enfim, os questionamentos são variados e nem para tudo se tem respostas, mas muitas vezes mais questionamentos advêm o que torna instigante os estudos. Conforme Mary Del Priore (2009, p. 9)

[...] Se isso não bastasse, ainda poderíamos nos perguntar: para que serve a história das mulheres? E a resposta viria, simples: para fazê-las existir, viver e ser. E mais, fazer a história das mulheres brasileiras significa apresentar fatos pertinentes, ideias, perspectivas não apenas para especialistas de várias ciências - médicos, psicólogos, antropólogos, sociólogos, etc. -, como também para qualquer pessoa que reflita sobre o mundo contemporâneo, ou procure nele interferir. Esta é, afinal, uma das funções potenciais da história.

E esta fala de Del Priore (2009) mostra a importância de estudar a história das mulheres que foi omitida pelos escritores porque por muito tempo não era interessante, rentável falar e escrever sobre as mulheres, suas identidades, desejos, frustrações. A partir do momento em que há a escrita sobre as mulheres e pelas mãos de autoras a história toma outra configuração. Conforme Beauvoir (1981, p. 9) "A mulher não nasce mulher, faz-se mulher, é a sociedade que a faz mulher" (apud, Cavalcanti \& Blanchard, 2014, p. 16). E se a sociedade a exclui de ser vista como ela deseja ser apresentada então vem 
à tona uma falsa identidade feminina que perdurou por muitos anos e em muitas culturas ainda se vê, com o olhar ocidental, uma opressão as identidades femininas. Conforme Hall (1994)

[...] a identidade é uma espécie de fator coletivo partilhado por pessoas da mesma história e ascendência. A problematização em torno da identidade das mulheres antecede o movimento feminista propriamente dito. O substrato ideológico do esforço das "feministas" originais, como Aphra Behn, Mary Wollstonecraft, Nísia Floresta e outras, visava à aquisição da identidade por todas as mulheres através de sua importância não derivativa nas esferas pública e privada (apud Bonnici, 2007, p. 146).

O que Bonnici (2007) destaca do pensamento de Hall (1994) é o valor que deve ser dado à luta feminista que veio buscar essa identidade para as mulheres. De acordo com Guacira Lopes Louro (2018, p. 10), "Hall (1997) já falava sobre a 'política de identidades' em que novas identidades sociais começaram a aparecer desde 1960 e com isso seriam construídas novas formas de relacionamentos". E, essas políticas de identidade conforme Woodward (2013, p. 34 - 35) diz que era o que definia

[...] esses movimentos sociais, marcados por uma preocupação profunda pela identidade: o que ela significa, como ela é produzida e como é contestada. A política de identidade concentra-se em afirmar a identidade cultural das pessoas que pertencem a um determinado grupo oprimido ou marginalizado. Essa identidade torna-se, assim, um fator importante de mobilização política. Essa política envolve a celebração da singularidade cultural de um determinado grupo, bem como a análise de sua opressão específica.

As políticas de identidades vêm realmente para mexer com toda uma estrutura social deixando bem visível, de acordo com o que Woodward (2013) destacou, seu poder político de mobilização, em especial com os marginalizados e oprimidos. E, Louro (2018, p. 13) acrescenta que

É, então, no âmbito da cultura e da história que se definem as identidades sociais (todas elas e não apenas as identidades sexuais e de gênero, mas também as identidades de raça, de nacionalidade, de classe, etc.). Essas múltiplas e distintas identidades constituem os sujeitos, na medida em que esses são interpelados a partir de diferentes situações, instituições ou agrupamentos sociais. Reconhecer-se numa identidade supõe, pois, responder afirmativamente a uma interpelação e estabelecer um sentido de pertencimento a um grupo social de referência. Nada há de simples ou de estável nisso tudo, pois essas múltiplas identidades podem cobrar, ao mesmo tempo, lealdades distintas, divergentes ou até contraditórias. Somos sujeitos de muitas identidades. Essas múltiplas identidades sociais podem ser, também, provisoriamente atraentes e, depois, nos parecerem descartáveis; elas podem ser, então, rejeitadas e abandonadas. Somos sujeitos de identidades transitórias e contingentes. Portanto, as identidades sexuais e de gênero (como todas as identidades sociais) têm o caráter fragmentado, instável, histórico e plural, afirmado pelos teóricos e teóricas culturais.

Essas identidades que o sujeito vai somando em sua trajetória é o que vai fazê-lo real, único, dono de sua jornada para viver a transitoriedade de suas próprias identidades. A Identidade Feminina entra nesse contexto a partir do momento em que a mulher reconhece-se no que vive e puxa para si características que somam com sua personalidade. Desta forma é de suma importância as representatividades femininas nos vários setores da sociedade, na literatura, na política, na religião, na economia, enfim a mulher encontrar-se nas outras mulheres que já se libertaram ou que estão em busca da libertação.

\section{Memória Docente: Narrativas que Contam Histórias}

Dentro das narrativas o que tem grande importância, além do conteúdo/história que será contada e a forma que será narrada, é quem conta tal história. Quem é o narrador ou narradora que por muitas vezes terá mais a atenção do leitor do que as personagens. E isso ocorre porque há narrativas que necessitam de um narrador que explique para quem lê o que está acontecendo, os caminhos da história. Como está escrito no Dicionário de Termos Literários de Massaud Moisés (2004, p. 
315) o narrador é alguém "confiável” ou "inconfiável” e Gérard Gennete (1972, p. $267^{4}$ apud Moisés, 2004, p. 315) acrescenta que: "O verdadeiro autor da narrativa não é somente aquele que a conta, mas também, e por vezes com vantagem, aquele que a escuta".

E assim o leque é estendido também ao leitor que por vezes será o narrador em algum momento de sua vida ao repassar tal história lida com atenção. Neste estudo não se entrará no âmago das questões com tipos de narradores e aplicações dentro do texto, mas somente para mostrar o quão importante é o papel deste dentro de uma narrativa, e no caso deste estudo, a memória docente e a narrativa dos professores. É importante ressaltar que existem vários tipos de narrativas e que o autor/autora é quem vai dá o seu estilo e fazer a diferença na composição de sua narrativa. Assim, Bonnici (2007, p. 190) apresenta a narrativa de procura, que segundo ele é

A narrativa linear, ou seja, a narrativa de sequência temporal e, portanto, de causa e efeito nessa mesma ordem, é uma estrutura dominante narratológica ocidental nos séculos 19 e 20. De fato, esse tipo de narrativa tem uma carga ideológica porque privilegia a sequência linear e descarta ou ignora a narrativa de fluxo de consciência ou a narrativa circular. Há diferenças significativas na maneira como os protagonistas masculinos e feminismos realizam a procura nas narrativas tradicionais. Nessas narrativas não-feministas (...) o herói tem a iniciativa de realizar a procura, vencer as dificuldades e sair vitorioso sobre os inimigos. A protagonista geralmente é passiva, é o próprio objeto da procura, sofre humilhações e adapta-se às demandas das circunstâncias mediadas pelo homem (grifos do autor).

Essa narrativa trazida por Bonnici (2007) é bastante comum em muitos textos por apresentar uma sequência temporal, mas existem outras formas bem interessantes também de escrever uma narrativa, porém o que vai chamar a atenção na fala do autor é quando ele menciona o modo como a protagonista feminina e o masculino fazem a sua "procura" no enredo da história narrada. Ele destaca que são narrativas "não-feministas", ou seja, o protagonista masculino é o herói, luta, vence as dificuldades e inimigos conforme a tradição sexista com o homem que "sai de casa, vai à rua, provém o sustento do lar". E a protagonista feminina é aquela mulher que sofre humilhações, é recatada, passiva e que se adequa as situações de convívio de "seu herói”, aquele ideário que é tão combatido pelas feministas até nos dias atuais. E, esse tipo de narrativa ainda é muito aceita por diversos leitores. Neste estudo foi apontado, mas o que será visto nas análises são as narrativas autobiográficas dos docentes que poderão trazer características de muitos estilos testemunhais, masculinos, femininos, neutros, traumáticos, indiferentes, ficcionais ou outro que ainda possa ser detectado na análise.

E tendo por base a narrativa autobiográfica dos sujeitos desta pesquisa, Jovchelovitch \& Bauer $^{5}$ (2002, p. 110 apud Abrahão, 2003, p. 91- 92) mostram algumas características das narrativas por conta da realidade ou representação desta no meio social, assim, observa-se que:

1) A narrativa privilegia a realidade do que é experienciado pelos contadores de história: a realidade de uma narrativa refere-se ao que é real para o contador de história; 2) As narrativas não copiam a realidade do mundo fora delas: elas propõem representações/interpretações particulares do mundo; 3) As narrativas não estão abertas à comprovação e não podem ser simplesmente julgadas como verdadeiras ou falsas: elas expressam a verdade de um ponto de vista, de uma situação específica no tempo e no espaço. 4) As narrativas estão sempre inseridas no contexto sócio-histórico. Uma voz específica em uma narrativa somente pode ser compreendida em relação a um contexto mais amplo: nenhuma narrativa pode ser formulada sem tal sistema de referentes.

Conforme Jovchelovitch e Bauer (2002) há a valorização da realidade narrada pelos que contam a história, não importando se é ficção ou não porque há a interpretação particular de cada um/uma ao escrever o que sente ou pensa e não

\footnotetext{
${ }^{4}$ Genette, Gérard. Figures III. Paris: Seuil, 1972.

${ }^{5}$ Jovchelovitch, S. \& Bauer, M. W. A Entrevista Narrativa. In: Bauer, M. W. \& Gaskell, G. Pesquisa Qualitativa com texto Imagem e Som - um manual prático. Petrópolis: Vozes, 2002, p. $90-113$.
} 
cabe juízo de valor porque cada uma tem a sua verdade pelo ângulo que enxerga e a narrativa deve estar sempre dentro deste contexto social-histórico.

As mulheres que no decorrer dos anos foram silenciadas e que conseguiram publicar suas obras para que estas fossem difundidas a homens e mulheres em vários lugares no mundo levaram sua narrativa inteligente, traumática, fêmea, militante, telúrica, saudosa, engraçada, esperançosa, erótica, sensual, criativa, feminina, enfim, usaram de suas experiências para que outras pessoas pudessem ler o que elas estavam sentindo com tudo que lhes acontecia. Como Seligmann-Silva (2005, p. 87 apud Alves, 2017, p. 110) expôs: "O testemunho possui um papel de aglutinador de um grupo de pessoas (...) que constroem a sua identidade a partir dessa identificação com essa memória coletiva de perseguições, de mortes e dos sobreviventes." E, assim, apesar das feridas que as lutas pelo direito das mulheres precisou travar, as autoras tiveram forças para fazer narrativas e espalhar ao mundo o quanto cada uma é forte o suficiente para ser independente, empoderada, múltipla, sensível e muito mais sem precisar menosprezar a dor de ninguém, mas buscar sempre a justiça para que outras mulheres se identifiquem com o poder que emana de cada uma para galgar seu espaço.

\section{Resultados e Discussão das Memórias Docentes da LAF}

A memória docente abarca muitas situações do convívio escolar e extraescolar, mas ao serem entrevistados sobre a memória que estes docentes tinham da LAF surgiram muitas respostas que auxiliaram bastante este estudo. Assim, para este artigo foram feitos recortes de muitas falas, por conta do espaço que um artigo proporciona. Mas o que está sendo posto aqui responde ao objetivo delineado. Então, aqui se busca na memória dos docentes do Curso de Letras as lembranças que estes têm da literatura escrita por mulheres e o que eles/elas fazem com estas memórias na hora de lecionar para futuros professores. E, os que já são egressos do Curso, como estão repassando o que aprenderam, sobre a LAF, nas escolas onde lecionam.

Desta forma, os elementos que constituem as narrativas dos/das professores/as partem de suas memórias individuais, coletivas e/ou históricas que aliadas às experiências de formação escolar e não escolar trazem para este estudo materiais significativos para as análises que buscarão mostrar indícios de memórias docentes da LAF e se essas memórias influenciam nas aulas desses/as professores/as.

A professora egressa Ana Cesar (fevereiro de 2021) disse que foi despertada para a LAF na universidade quando fez seu Curso de Letras e ainda ressalta que conheceu mais autoras na Literatura infanto juvenil do que as autoras presentes em outras Literaturas como a Literatura Regional, Brasileira, Norte-Americana, Portuguesa e Inglesa. E as professoras abaixo também tiveram seu primeiro contato com a LAF na vida acadêmica e alguns ainda relatam até a metodologia que os professores e professoras empregavam em suas aulas. Assim,

Já na faculdade é que fui intensificar meu conhecimento sobre a literatura. De maneira geral, os professores trabalhavam em equilíbrio, tanto com escritores homens, quanto mulheres. Eram excelentes. Tínhamos leituras variadas em ambas as literaturas, líamos Violeta Branca, Cecília Meireles, Emilly Dickson, Jane Austen, Clarice Lispector, Raquel de Queiroz, entre outras. Eram debates em sala de aula, comentários sobre a escrita feminina, suas peculiaridades. Minha formação acadêmica foi muito boa, tive a oportunidade de aprender com professores muito bons, que tinham ampla experiência, além de despertarem o interesse pela paixão com que desempenhavam o vício. Saí da UFAM em janeiro de 2015. (Sylvia Plath, fevereiro de 2021).

Minha formação educacional foi muito boa! Saí no ano de 2019 e vivenciei o ensino de literatura na Graduação. No ensino fundamental não lembro, pois faz tempo que concluí. Mas na graduação as aulas de literatura de modo geral eram muito boas, prazerosas e divertidas. Com isso, nos levava a conhecer um mundo de coisas novas da literatura, era muito gostoso assistir aulas de professores tão competentes e sábios como os professores: Douglas, Raquel, Elis Regina e entre outros. Eu amava as aulas de literatura Infanto juvenil. Também haviam professores que levavam obras de autoria feminina. Então, nas aulas de literatura brasileira conheci algumas escritoras e obras brasileiras como: Clarice Lispector, Rachel de Queiroz, Cecilia Meireles... As aulas sempre ocorriam com a apresentação da autora e biografia. Geralmente nos perguntavam se conhecíamos alguma obra se a resposta fosse positiva a gente 
compartilhava sobre a mesma em seguida adentrávamos mais para o interior do assunto (Kate Chopin, fevereiro de 2021).

Minha formação acadêmica em nível superior foi ótima tanto em âmbito profissional, quanto pessoal. Concluí a graduação em 2017. A formação básica não me proporcionou um encontro produtivo no que se refere à literatura, comecei a ter contato com literatura na Universidade. O meio acadêmico me apresentou várias possibilidades de enxergar a literatura como construção social e cultural. Minha formação literária foi bem justa no que diz respeito ao valor da fala feminina frente à fala masculina, ou seja, não há distinção entre ambos os gêneros no que se refere a politização de um tema. Em todas as literaturas os professores apresentavam obras de autoras mulheres, discutíamos os textos e sempre enfatizávamos a importância da fala feminina nas aulas de literatura (Clarice Lispector, fevereiro de 2021).

Entrei na UFAM em 2014 e saí em 2018. Em relação à autoria feminina, vi somente no ensino acadêmico. Lá sim, se discutia na sala sobre a importância dessa equidade entre escritores e escritoras. Nas aulas de Literatura, independente de qual delas, eram sempre ressaltadas autoras mulheres. Os professores sempre tinham essa preocupação. Uns mais, e outros menos. Não sei como eles faziam as escolhas das obras, mas lembro que ressaltavam que havia também autoras femininas, uma ou duas (Emily Brontë, fevereiro de 2021).

No ensino fundamental e no ensino médio não foram apresentadas autoras feministas, conheci algumas autoras apenas no Curso de Letras. Apesar do pouco convívio com tais autoras sempre gostei de que houvesse a equidade entre os sexos com relação a obras apresentadas em nossa grade enquanto graduando. Nas aulas das respectivas disciplinas sempre havia apresentação de autores de ambos os sexos, mesmo assim havia uma enorme diferença entre autoras femininas e autores masculinos. (Florbela Espanca, janeiro de 2021).

As narrativas feitas pelos/as professores/as egressos/as demonstra que a formação inicial foi objetiva em apresentar a LAF para todos e todas que quiseram aventurar-se pelo mundo da Literatura escrita por mulheres. O que os sujeitos da pesquisa relatam demonstram que a formação inicial do professor e da professora é fundamental para que este processo fique mais visível e a grade curricular dos egressos é a de 2006/2 que não tinha o acréscimo que agora têm na de 2019/2 com a Introdução à leitura de textos literários, Leitura em Língua Inglesa, Metodologia do Ensino de Língua e Literatura, duplicação da Literatura Inglesa e Norte-Americana além das optativas como

História da Literatura, Literatura Universal, Literatura e cinema: introdução aos estudos da adaptação, Literatura Infanto Juvenil de Língua Inglesa, Introdução as Literaturas Africanas de Língua, Literatura Comparada, Crítica Literária, Literatura e Feminismo, Literatura Pós-colonial, Literatura, Memória e História, O Conto Amazônico, Poesia Amazônica, Letramento, Literatura Parnasiana e Simbolista, Linguística Textual, Literatura Latina (IEAA, 2019, p. 30).

A grade curricular de 2006/2 não tinha esse olhar para a LAF em suas disciplinas e ementas, mas conforme a narrativa dos egressos, que agora estão docentes na rede pública de ensino, os professores formadores usando de suas metodologias encaixavam essa problemática e traziam para as aulas a LAF que era, de alguma forma, apresentada aos discentes em formação. E sobre isso Oliveira acrescenta: “O que implica afirmar que será necessário que o(a) docente, por vezes, espere, indique percursos e auxilie os(as) discentes na superação dos obstáculos” (2021, p. 33). Foi o que ocorreu com os próprios docentes formadores ao trazerem para suas aulas o que estava faltando em sua grade curricular e também o que aconteceu com alguns dos sujeitos que relataram suas dificuldades e, ao que tudo indica, a força interior deles/delas aliada ao bom acompanhamento de seus formadores os/as levou a colação de grau e hoje atuam como docentes também.

Vale destacar que no IEAA têm outros cinco cursos de graduação e é de suma importância que as mulheres e homens que estão neste processo formativo inicial também tenham acesso a este tipo de formação para que se abram outros prismas e também deem oportunidade para que a LAF possa auxiliar no processo identitário de outras pessoas. É um desafio, com certeza, pois ir contra um sistema que exclui é, por vezes, colocar-se como alvo para este que ataca. E em relação à identidade é de suma importância ter e reconhecer-se em sua(s) identidade(s), conforme Hall (2006, p. 9) "Um tipo diferente de mudança estrutural está transformando as sociedades modernas no final do século XX.” E com isso “está fragmentando as paisagens 
culturais de classe, gênero, sexualidade, etnia, raça e nacionalidade, que, no passado, nos tinham fornecido sólidas localizações como indivíduos sociais." E agora se configura outra identidade chamada de pós-moderna que já deixou para trás a identidade do sujeito do iluminismo e do sujeito sociológico.

A identidade pós-moderna é descentralizada e as pessoas são atravessadas por diversas culturas porque o mundo está em constante evolução tecnológica, midiática, intelectual, com movimentos sociais, políticos, mudanças comportamentais, estruturas religiosas que se ampliam, enfim, não se tem mais em mente aquele trabalho para uma vida inteira, como era no tempo do sujeito do iluminismo em que se nascia escravo e deveria ser sempre serviçal.

Hoje a busca por espaços, inalcançáveis anteriormente, é possível. Os casamentos podem ser para sempre ou não. Ninguém tem mais a obrigação de carregar consigo outra pessoa apenas por conveniência social, como muitas mulheres sofreram. O ser humano na pós-modernidade tem múltiplas identidades porque ninguém é uma "coisa só". Por exemplo, uma professora, pode ser mãe, conselheira na igreja que participa, ciclista, membro do sindicato dos professores, líder de bairro, além de ser filha, amiga, esposa e assim por diante. São muitas identidades e nem todas são para sempre, mas transitórias como afirma Hall (2006).

Sobre esta parte é importante salientar que rememorar questões pessoais e profissionais com os/as professores/as egressos/as e os/as formadores/as do curso de Letras do IEAA, que trabalham com a Literatura, Linguagem e Língua Portuguesa vivem essa identidade pós-moderna quando se observa que eles/elas exercem múltiplas funções pessoais, sociais e profissionais no seu dia-a-dia com jornadas gigantes, que por conta da pandemia, tornaram-se inteiramente disponíveis para seus alunos porque o whatsapp e a internet facilitam, mas também criam essa dependência.

E, mesmo com essa correria que está sendo este período de pandemia, vale destacar que alguns dos sujeitos desta pesquisa estão conseguindo fazer mudanças em suas salas de aulas com a aplicação da LAF, outros almejam implementá-la em breve. E eles/elas ainda relatam sobre o porquê de levar as autoras para suas aulas e quais as vantagens de tê-las neste processo. Desta forma, serão postos os recortes de suas falas para que se possam identificar essas afirmativas e aqui se inicia esta parte do estudo com as narrativas das memórias docentes dos sujeitos que trazem algumas respostas aos questionamentos deste estudo como a professora formadora Virginia Woolf (2020) sobre sua memória acerca da LAF em sua caminhada educacional em que relatou:

Bom... ao longo da minha vida eu tive curiosidade de ler autoras, mas era uma curiosidade de alguém leigo, de uma pessoa que não entende essa coisa de autoria feminina. Assim, sobre a literatura de autoria feminina, falando primeiro das coisas que eu li ao longo da minha vida, já durante a minha adolescência eu comecei a ler muito, ler tudo! Tudo que eu achava na biblioteca e aí eu comecei a ler algumas autoras que na época eu era muito nova pra saber quem era, mas eu comecei a ler Clarice Lispector, Lygia Fagundes Telles e algumas outras autoras, mas assim espaçadamente. Nada que fosse uma leitura constante, nada que eu refletisse sobre a escrita feminina. Essa reflexão começou com um pouquinho mais de força durante a graduação porque eu comecei a ter professoras de Literatura que levaram obras de autoria feminina. Então, por exemplo, eu tive a disciplina de Contos, de Literatura Anglo-Americana porque eu fiz a Literatura Inglesa e Norte Americana tudo junto. E, para disciplina de Contos eu tive uma professora que levou várias autoras femininas! Uma delas que me marcou muito foi a Kate Chopin da Literatura Norte-Americana que até hoje eu levo pra os meus alunos porque foi muito marcante ver uma escritora de 1890 falando de independência sexual feminina, por exemplo, e isso foi extremamente marcante. Depois eu tive a Charlotte Perkins Gilman que escreveu Papel de parede amarelo e essas histórias, esses contos ficaram muito marcantes na minha graduação. Também tive a disciplina de Romance e todos os professores foram levando a autoria feminina. Só que nada neste período foi muito refletido, pensado como: Olha a autoria feminina! Olha como as mulheres escrevem! É engraçado que a minha graduação ela foi extremamente tradicional, tradicionalista neste sentido. A gente não tinha essa reflexão sobre a autoria feminina e aí quando eu entrei no mestrado tinha uma disciplina de Literatura de Autoria Feminina e Feminismo só que foi muito curioso porque eu não pude fazer, fiquei frustrada porque eu queria muito fazer. Nessa época eu estudava no mestrado, mas trabalhava. Então eu tinha que encaixar as disciplinas que eu ia fazer em dias da semana pra que eu não perdesse muitos dias de trabalho. E a disciplina de Literatura de Autoria Feminina era justamente uma que eu não podia fazer porque ela era num dia da semana, acho que era na segunda-feira, e eu ia ter que perder um dia inteiro de trabalho pra fazer. Infelizmente, olha como o mundo capitalista nos constrange. Eu fico 
constrangida porque eu queria muito ter feito essa disciplina. Então, eu confesso que ao longo da minha graduação isso foi muito falho. Eu tive lances, situações, professoras levando curiosidades, leituras, mas nada foi muito refletido (dezembro, grifos da autora).

A professora faz um breve relato de sua vida como discente e é importante observar que esta memória que ela traz, mesmo sendo individual por ser uma vivência dela, segundo Halbwachs (2006) ela não viveu sozinha, havia os outros estudantes da graduação, pessoas na biblioteca onde ela ia pegar livros, por exemplo, que compartilham de suas lembranças e, por isso mesmo, são memórias coletivas. E, referente à LAF na vida dela pode-se notar que as escritoras vieram, mas ela não entendia o mundo das mulheres como os entende agora, porém chama a atenção que houve a leitura identitária com autoras e que hoje, ao dar suas aulas, as leva para apresentar a suas alunas. Sobre este assunto da memória docente dos professores e suas lembranças sobre a LAF tem destaque esta outra narrativa feita pela professora formadora Andréa del Fuego (dezembro de 2020) em que diz

Li Clarice Lispector, Lygia Fagundes Telles, Rachel de Queiroz porque ouvia falar delas, porque eram citadas em livros didáticos, porque ouvi ou li coisas em jornais (na minha casa, sempre comprávamos o jornal "Folha de São Paulo" aos fins de semana, e eu lia as colunas de artes, literatura, etc.). Assim, eu frequentava uma biblioteca próxima de minha casa. Acho que peguei o primeiro livro da Clarice nessa biblioteca por ter já ouvido falar ou lido algo sobre a autora. Isso ocorreu no ensino médio. No fundamental, lia mais livros da "Coleção Vaga-lume", da Editora Ática, livros, em geral, de aventura. E outros livros indicados pelos professores durante as aulas de língua portuguesa. Não me recordo de escritoras, a não ser Cecília Meireles, cujos poemas sempre figuraram em livros didáticos. Durante toda minha formação até a graduação, nunca pensei na literatura em termos de autoria masculina ou autoria feminina. Estudei em uma instituição de ensino superior bastante ligada aos cânones e à chamada alta literatura. Fui tomar um pouco de consciência deste recorte e de sua importância no meu segundo mestrado, quando tomei mais contato com a crítica literária feminista. Não obstante, não ter essa memória em torno de literaturas de autoria feminina, houve e há até hoje em minha memória afetiva uma autora em especial, Clarice Lispector, que comecei a ler ainda na adolescência, no ensino médio. Ela é uma artista genial. Uma excepcionalidade dentro da literatura brasileira e da literatura mundial. Adoro os textos dela e sempre releio várias de suas obras. Lembro que a primeira vez que entrei em uma escola para lecionar, em 2004, eu estava com um livrinho de contos dela. Não sabia bem o que faria na escola, então pensei que poderia ler um conto dela para as turmas que assumiria (era metade do semestre letivo). Por uma infelicidade, a morte de um professor da escola, houve luto por uma semana. Então não me socorri da literatura dela, o que poderia talvez ser bem confuso para os alunos na ocasião... Mas a Clarice esteve lá me apoiando... Mas, além dela, havia a literatura canônica do século XIX e início do século XX que esteve sempre como referência para mim, em minhas aulas de literatura, seja na educação básica ou superior.

A professora Andréa del Fuego (2020) destaca uns pontos muito importantes neste estudo sobre a questão da memória docente em que se observa que ela tem uma memória individual sendo relatada, mas que vem carregada de lembranças coletivas em que aparece mais uma vez o espaço da biblioteca como lugar para leitura e, com certeza, havia uma bibliotecária para anotar os livros lidos pela professora, o espaço da sala de aula em que os livros eram indicados pelos professores de língua portuguesa, as autoras que figuravam nos excertos nos tais livros didáticos como ela cita: Clarice Lispector, Lygia Fagundes Telles, Rachel de Queiroz, Cecília Meireles e assim as lia porque eram citadas em livros didáticos ou colunas de jornais ou algo do gênero.

Chama atenção o fato de ela falar que "estudei em uma instituição de ensino superior bastante ligada aos cânones e à chamada alta literatura" e até a graduação, especificamente até seu segundo mestrado não havia parado para pensar em LAF o que só veio à tona em sua vida ao cursar o seu segundo mestrado em que teve contato com a crítica literária feminista. Em sua vida como docente a autora que ficou em sua memória e que leva para suas aulas, quando vai explicar sobre o seu período na literatura brasileira, é a Clarice Lispector porque, segundo ela, é "uma artista genial” e em, determinado momento de sua vida em que foi lecionar pensava em levar um conto de Clarice, mas não foi necessário. Então disse que "a Clarice esteve lá me apoiando" e acrescenta "mas, além dela, havia a literatura canônica do século XIX e início do século XX que esteve sempre como referência para mim, em minhas aulas de literatura, seja na educação básica ou superior”. Essas falas da professora 
trazem para este estudo a confirmação de uma presença arraigada, no ensino brasileiro, da literatura canônica masculina e algumas poucas autoras como as citadas pela professora formadora Andréa del Fuego.

Também se ressalte que ela, por ter tido formação em uma instituição bastante ligada ao cânone é retransmissora dessa tradição, sem procurar encaixar as lutas feministas ou autoras silenciadas durante as explicações da literatura brasileira em suas aulas. Porém, enxerga-se que a professora se identifica com a autora Clarice Lispector e que já percebeu que há a crítica literária feminista e, quem sabe isso não seja um indício de mudanças em sua metodologia.

Já a professora formadora Simone de Beauvoir (janeiro de 2021) disse a respeito de suas memórias que "minha primeira obra lida foi uma adaptação de Romeu e Julieta da Ruth Rocha, sempre que posso trabalho com essa obra na versão de Shakespeare. Amo fazer leitura dramatizada", ou seja, há a presença da LAF em sua memória individual e coletiva. Além do mais repassa tal experiência aos discentes. $\mathrm{E}$ ainda acrescentou que também trabalha com o cânone masculino brasileiro e universal "outras também me tocam muito: Memórias Póstumas de Brás Cubas do Machado de Assis, Lolita de Nabokov, são tantas, as revisito sempre, e continuo lendo mais e mais coisas da Literatura Universal". E isso leva a pensar que a cultura é múltipla, é híbrida em que acolhe a todos sem hierarquizar (Bhabha, 2013), como faz a professora Simone de Beauvoir que não impõe barreiras para o conhecimento chegar até quem deseja recebe-lo, valoriza as literaturas de diversas nações.

A professora formadora Simone de Beauvoir (2021) também afirmou: "nunca separei as obras, a não ser no presente momento, que tenho lido bastantes autores transgêneros, então não houve um momento em que tenha lido somente literatura de autoria feminina ou masculina" e o que afirma também vai de encontro com o movimento feminista que sempre pregou a busca pela equidade e, no caso da fala da professora, há a sustentação de que a literatura pode despertar esta sensação ou estado de igualdade literária sem precisar vangloriar uma em detrimento da outra, mas as trabalhar sem distinções, marginalizações. Conforme afirma Coelho (1993, p. 12):

[...] a atenção que a produção literária das mulheres vem exigindo da crítica (como fenômeno que é, em meio à produção geral) não se identifica com uma intenção judicativa. Não se trata de saber se a literatura "feminina" é melhor ou pior que a "masculina" (pois isso não teria nenhum sentido...), mas sim descobrir o que ela é, como se constrói e por que trilha determinados caminhos (grifos da autora).

A autora destaca esta posição de equidade defendida pelo movimento feminista e posto em prática na fala da professora formadora Simone de Beauvoir. Além disso ressalta que a literatura feminina busca descobrir-se no que é, como se constrói e por que trilha seus caminhos da forma como faz para que assim possa se apresentar ao seu leitor ou leitora.

Sendo assim percebe-se na fala dos sujeitos que suas memórias corroboram para valorização do ensino da LAF tanto no ensino básico quanto no ensino superior. No ensino básico porque é a formação educacional das crianças, adolescentes e jovens que estão em fase de desenvolvimento em vários âmbitos e necessitam conhecer a mulher como escritora para também irem valorizando ou identificando-se com suas temáticas. E, no ensino superior, especialmente nas licenciaturas porque são os professores em formação que levarão estes conhecimentos para os estudantes do ensino básico e superior mas, se não houver um preparo na formação inicial como será a divulgação deste conhecimento que não foi trabalhado no ensino superior.

Assim, a professora egressa Carolina Maria de Jesus (janeiro de 2021) afirma que levar as obras de mulheres para suas aulas a fez

[...] ler mais acerca de escritoras brasileiras, por esse motivo fui pesquisar mais sobre Carolina Maria de Jesus, pois quero mostrar aos meus alunos que negros não foram apenas escravos como muito livros de histórias os descrevem, eles tinham uma vida antes da escravidão e, consequentemente, depois também. Tenho anseio de mostrar quem são essas pessoas na literatura, em especial mulheres, pois eu mesma conheço pouquíssimas. Sinto a necessidade de aprender sobre mulheres que tiveram grande importância na nossa história literária e que, por algum motivo, foram postas de escanteio. 
A professora egressa Carolina Maria de Jesus é uma mulher negra que se identificou com os escritos da autora e outras mais. E esse conhecimento não está guardando unicamente para si, mas buscando divulgar aos estudantes com os quais compartilha suas experiências. Outras professoras que estão levando essas experiências para sala de aula narram suas experiências da seguinte forma:

Busco escritoras que tenham linguagem mais acessível ao nível de conhecimento dos alunos. [...] geralmente levo as que tive acesso na graduação. Penso que é importante divulgar o trabalho de mulheres, já que geralmente o clássico é sempre masculino (Sylvia Plath, fevereiro de 2021, grifos da autora).

Como atuo recentemente na área, não tivemos muitas aulas presenciais, com tudo apresentei algumas autoras como Conceição Evaristo, Clarice Lispector, Cecília Meireles. Em minhas aulas gosto de praticar a equidade entre ambos os sexos (Florbela Espanca, janeiro de 2021).

Acho importante mostrarmos aos nossos alunos a atuação das mulheres na literatura. E já o fiz. Em 2019, por exemplo, trabalhei seminários com os $2^{\circ} \mathrm{s}$ anos do médio no qual as obras estudadas eram todas contos da escritora Lygia Fagundes Telles, e os próprios alunos, em suas pesquisas, puderam perceber o quão essa escritora é importante dentro da literatura do nosso país (Ana Cesar, fevereiro de 2021).

Tenho muito interesse em levar autoras mulheres em minhas aulas, quando lecionava literatura procurava mencionar as autoras dentro de cada movimento literário de seu tempo, mas confesso que a representatividade é bem menor em relação aos autores homens no cânone literário. Tive alguns trabalhos de escritoras analisados durante as minhas disciplinas de graduação, e considero importante dar visibilidade a essas escritoras (Virginia Woolf, dezembro de 2020).

Como afirmei, levo as autoras quando elas estão relacionadas às disciplinas que leciono. Não vejo como falar de autoria feminina, por exemplo, ao tratar das instituições literárias dos séculos XVI, XVII, XVIII ou mesmo XIX, porque há mesmo uma falta, uma lacuna, tanto em minha formação quanto não há materiais ou autoras facilmente identificáveis com as quais se pudesse desenvolver alguma leitura ou análise em sala de aula. Falar de "autoras mulheres" significa também adotar certa perspectiva crítica, o que talvez não se relacione com minha formação, meus conhecimentos. Não há um ponto neutro a partir do qual possa se falar de determinada obra ou autor. Se eu me considero um estruturalista, ou um formalista, ou um feminista, ou assumo ecleticamente diferentes conceitos, de diferentes correntes críticas, falarei de diferentes "autoras" sob diferentes pontos de vista. Assim, não sei se penso na questão de que devo ou não "incluir autoras" em minhas aulas, porque isso está ligado estritamente aos objetivos gerais das disciplinas, que, em geral, em nosso curso de Letras está bastante ligado em fazer uma apresentação e um panorama histórico de autores e obras que a maior parte dos discentes nunca tiveram ainda acesso a não ser quando adentram a própria universidade (Andréa del Fuego, dezembro de 2020).

Assim os sujeitos narram o quão imprescindível é levar mulheres autoras para suas aulas porque conforme disseram: "é importante divulgar o trabalho de mulheres", "praticar a equidade entre ambos os sexos", "mostrarmos aos nossos alunos a atuação das mulheres na literatura", "considero importante dar visibilidade a essas escritoras", "levo as autoras quando elas estão relacionadas às disciplinas que leciono". E, desta forma a LAF vai chegando ao público do ensino básico e ensino superior.

Observa-se as falas das professoras formadoras Virginia Woolf e Andréa del Fuego no ponto em que diz respeito ao ensino de LAF tendo como empecilho o cânone masculino em séculos de Literatura. A professora formadora Virginia Woolf (2020) narrou que "procurava mencionar as autoras dentro de cada movimento literário de seu tempo, mas confesso que a representatividade é bem menor em relação aos autores homens no cânone literário (grifos nossos)" e em contraponto a professora formadora Andréa del Fuego (2020) disse que "Não vejo como falar de autoria feminina, por exemplo, ao tratar das instituições literárias dos séculos XVI, XVII, XVIII ou mesmo XIX" e justifica sua fala ao dizer que "há mesmo uma falta, uma lacuna, tanto em minha formação quanto não há materiais ou autoras facilmente identificáveis com as quais se pudesse desenvolver alguma leitura ou análise em sala de aula (grifos nossos)”.

Assim, enquanto a professora formadora Virginia Woolf (2020) vai tentando explicar a seus alunos a ausência dessas autoras nesses longos períodos da historiografia literária e também busca "mencionar" as autoras, embora poucas, mas ainda 
resistentes e presentes nos movimentos literários. A professora formadora Andréa del Fuego (2020) diz não ver como fazer essa mostragem de autoras e ainda justifica-se que isso ocorre por conta do cânone masculino e também a formação que teve em uma universidade tradicional que, segundo ela, foi falha nessa questão, sente uma lacuna na história da literatura e na sua formação também.

A professora formadora Andréa del Fuego (2020) ainda acrescenta em sua fala que as disciplinas do Curso de Letras do IEAA têm por objetivos gerais "fazer uma apresentação e um panorama histórico de autores e obras que a maior parte dos discentes nunca tiveram ainda acesso a não ser quando adentram a própria universidade". Esta fala da professora Andrea reforça a questão do déficit no ensino de literatura e a importância de fazer esse resgate no ensino superior. E, Cosson (2014) aprofunda a fala da professora Andréa (2020) ao mostrar que há professores, no ensino médio, que se preocupam em fazer a historicização da Literatura e não fazem o incentivo a leitura e nem a análise de obras literárias masculinas e femininas. Conforme Cosson (2014, p. 23)

Seja em nome da ordem, da liberdade ou do prazer, o certo é que a literatura não está sendo ensinada para garantir a função essencial de construir e reconstruir a palavra que nos humaniza. Em primeiro lugar porque falta um objeto próprio de ensino. Os que se prendem aos programas curriculares escritos a partir da história da literatura precisam vencer uma noção conteudística do ensino para compreender que, mais que um conhecimento literário, o que se pode trazer ao aluno é uma experiência de leitura a ser compartilhada.

Desta forma as professoras e professores que vivenciam esta prática de ficarem presos às grades curriculares e transmissão da história da Literatura devem transpor esta fase e ir experienciar com seus discentes as obras literárias e as riquezas que estas trazem na prática da leitura literária. De forma alguma está sendo dito que não é importante saber a linha de tempo da literatura e suas características, mas que o estudo não se fixe nisso e que este vá além desses conceitos, períodos, marcações temporárias e que disponibilize o prazer das temáticas, estruturas narrativas, estilos de autoras/autores e muito mais.

Um outro ponto também mencionado na fala da professora egressa Sylvia Plath (2021) é referente ao que aprendeu sobre LAF na formação inicial e que hoje leva para suas aulas. Ela afirmou que "geralmente levo as que tive acesso na graduação" e com esta fala vale salientar o quão importante é o professor formador/a ser um leitor/leitora para inspirar seus alunos neste processo formativo como os que ajudaram na formação inicial da professora Sylvia Plath que hoje retransmite a seus alunos as autoras que conheceu em seu período formativo no Curso de Letras do IEAA e já ampliou seu conhecimento com outras autoras para continuar levando mais inspirações a seus alunos do ensino básico.

O Curso de Letras do IEAA demonstra que seus ensinamentos estão conseguindo chegar ao ensino básico da área ribeirinha e sede de Humaitá, Porto Velho, Manicoré e são estes sujeitos que aqui se encontram narrando suas experiências que embasam essa afirmativa. A LAF no ensino básico ou superior precisa de um preparo para ser apresentada e trabalhada com os discentes. Assim, há aqueles professores/as que ainda não levaram essa experiência para sala de aula, mas que estão estudando como farão isso em suas aulas

[...] Provavelmente faria pesquisas acerca das obras literárias para ver qual melhor introduzir em sala, tema, linguagem etc. Eu provavelmente não pesquisaria a Literatura por autor ou autora. Não teria essa visão de diferenciação de gênero. Por eu vim de uma cultura muito forte de literatura masculina, talvez não sentisse falta. Estou refletindo sobre isso agora (Emily Brontë, fevereiro de 2021).

[...] Trabalho no interior na comunidade ribeirinha chamada Muanense - Rio Madeira, lá as aulas remotas iniciaram em outubro de 2020, ou seja, praticamente não teve aula ano passado. Sem dúvida irei trabalhar literatura de autoria feminina com os alunos, mesmo não tendo uma disciplina na grade curricular a qual sinto falta (Kate Chopin, fevereiro de 2021). 
Poderia levar obras literárias de algumas autoras da Literatura Inglesa e Norte-Americana para a sala de aula para os alunos. [...] incluir algumas escritoras pelo fato de as ter estudado em minha formação e também porque sinto falta delas em minha grade curricular (Jane Austen, fevereiro de 2021).

A fala da professora egressa Emily Brontë (2021) vem destacar o quanto é forte a presença e o convencimento da literatura canônica masculina quando diz que "eu vim de uma cultura muito forte de literatura masculina, talvez não sentisse falta. Estou refletindo sobre isso agora", mas ao mesmo tempo traz expectativa de renovação quando diz refletir sobre a questão da LAF ao ser entrevistada para este estudo.

Já a fala da professora egressa Kate Chopin (2021) que trabalha na área ribeirinha de Humaitá pensa em levar a LAF para seus alunos do ensino fundamental II e enfatiza que "sem dúvida irei trabalhar literatura de autoria feminina com os alunos, mesmo não tendo uma disciplina na grade curricular a qual sinto falta". Percebe-se que a professora gosta de Literatura e que vai levar para seus alunos, mesmo não tendo especificamente uma disciplina de Literatura sob sua responsabilidade. Ela está fazendo uma intervenção para não deixar que o apagamento continue vigorando no ensino.

Outra professora que "sente falta" da disciplina de Literatura em suas aulas, por ter suas disciplinas todas voltadas para a língua inglesa, é a professora egressa Jane Austen (2021) que já disse querer: "incluir algumas escritoras pelo fato de as ter estudado em minha formação e também porque sinto falta delas em minha grade curricular”. Essa fala mostra o quão importante é apresentar as autoras no ensino superior para que os/as professores/as percebam o que está faltando na grade curricular que recebem para dar suas aulas, estudem como fazer para sanar o problema e tomem uma atitude para não deixar que esse silenciamento continue persistindo porque a LAF tem um significado muito grande para a formação tanto de mulheres quanto de homens.

E quando estes/estas professores/as vão lecionar e escolhem a LAF para suas aulas explicam que as selecionam porque "é preciso que eles conheçam as histórias e lutas de cada uma, pois elas contribuíram muito para a literatura feminina, por isso são importantes; sabemos que todas essas mulheres escritoras enfrentaram preconceito, o racismo, desrespeito, desvalorização justamente por serem mulheres" (Kate Chopin, 2021, grifo da autora), "Justamente pela questão de equidade que claramente vemos que é inexistente nesse quesito, seja no ensino fundamental, médio ou acadêmico, isso é um fato que precisa ser alterado porque precisamos conhecer e enaltecer as escritoras tanto quanto fazemos com os escritores" (Carolina Maria de Jesus, 2021). Nessas duas falas percebe-se que as professoras fazem questão de levar a LAF para que seus alunos não desconheçam a realidade das mulheres com suas lutas.

A professora egressa Florbela Espanca (2021) destaca que levar a LAF para seus alunos e alunas é uma oportunidade para que "o próprio aluno possa abrir um leque de conhecimento nesta área e assim faço ao máximo para que meus alunos possam conhecê-las". Desta mesma forma a professora formadora Virginia Woolf diz que leva as autoras para suas aulas porque é o momento que tem para "[...] dar igual visibilidade às mulheres [...] há um enorme benefício por introduzir literatura de autoria feminina na vida educacional das alunas, pois elas se veem representadas e empoderadas" e em outras palavras identificadas com aquelas que as representam.

Para que essa memória docente esteja em dia com sua formação faz-se necessário que os cursos de licenciatura invistam na formação inicial porque, conforme Tardif (2014, p. 288, grifo do autor) "a formação inicial visa a habituar os alunos - os futuros professores - à prática profissional dos professores de profissão e a fazer deles práticos reflexivos" o que Schön também já indicava ser um caminho possível e esta formação deve ser muito bem trabalhada pelo corpo docente de cada colegiado e vivenciada pelos acadêmicos/as que devem aproveitar cada informação e contato com o mundo externo à academia.

Outro ponto apontado neste estudo é a importância da formação continuada dos professores para que estes possam vir a se desenvolver ainda mais em sua práxis cotidiana. De acordo com Nóvoa (1992, p. 13): 
A formação deve estimular uma perspectiva crítico-reflexiva, que forneça aos professores os meios de um pensamento autônomo e que facilite as dinâmicas de auto-formação participada. Estar em formação implica um investimento pessoal, um trabalho livre e criativo sobre os percursos e os projetos próprios, com vista à construção de uma identidade, que é também uma identidade profissional.

E desta forma o professor e a professora conseguem criar "espaços de formação, de pesquisa, de inovação, de imaginação" (Imbernón, 2010, p.11) porque se lançam para um universo que permite a liberdade para ousar mais e mostrar aos discentes que eles e elas podem ir mais longe. E assim, na próxima subseção será visto o ensino da LAF e como os sujeitos dessa pesquisa estão trabalhando a partir de sua formação docente.

\section{Considerações Finais}

Falar da Literatura de Autoria Feminina em meio a um patriarcado que se instalou no Brasil e no mundo é um grande desafio. O machismo com que as mulheres são abnegadas de seus direitos por anos a fio é latente e pede por uma mudança de postura política, ideológica, educacional urgente. O movimento feminista veio contra todo esse patriarcado e até hoje ainda precisa posicionar-se para que as mulheres de "todos os tipos" possam exercer seus direitos e conquistar outros.

Ao trabalhar, tendo por objeto a memória docente dos/das egressos/as e professores/as formadores/as do IEAAUFAM, conseguimos detectar que estes/estas possuem muitas lembranças da LAF em suas vidas escolares e não escolares também. Também foi possível perceber algumas falhas referentes ao ensino de Literatura na educação básica e muitas vezes essas se projetam para o ensino superior fazendo com que seja necessário um letramento acadêmico.

Em relação a identidade feminina foi visto que os/as docentes conseguiram ter uma identificação com a LAF e estabeleceram um vínculo com a mesma que estão perpetuando a memória transgeracional (Halbwachs, 2006). E essa memória está sendo vivificada nas aulas dos/das docentes e em algumas dos/das docentes egressos. E os demais estão organizando-se para iniciarem as suas atividades implantando a LAF em meio aos conteúdos que têm nas disciplinas.

Desta forma o que vemos é um Curso de Letras dando bons frutos para Humaitá e adjacências uma vez que seus professores formadores investem em suas formações continuadas para buscar melhorias educacionais para seu corpo discente, futuros professores da região. E também enxergamos egressos atuantes em suas salas e que estão pondo em prática a formação inicial que tiveram. Com isso a LAF está ganhando novos/as leitores/as e quem sabe novos pesquisadores, escritores, multiplicadores da leitura escrita por mulheres.

Por fim, tendo em vista que a escrita feminina ainda tem focos de marginalização é necessário que aconteçam mais estudos sobre a LAF no ensino básico, superior, nas pós-graduações e também que se averigue a presença da escrita das mulheres nas Ciências e o quanto são valorizadas ou não no que escrevem. Existem indícios de que o campo da Ciência subjuga o conhecimento feminino. Outros pontos que podem ser trabalhados ainda nesta perspectiva da LAF nas instituições educacionais, é a ligação da mesma com o letramento literário defendido por Rildo Cosson e o letramento acadêmico que ajudaria muitos jovens e adultos ao iniciarem suas atividades educacionais no curso de formação superior, isso não significa que somente as licenciaturas teriam essa missão, mas todas as áreas do conhecimento. Além disso, existem outros campos que devem ser visitados e estudados para que a LAF ajude outras pessoas a descobrirem-se maiores do que imaginam. É necessária a inserção de políticas públicas educacionais, trabalhistas, segurança pública e muito mais para que as vozes femininas saiam do porão da exclusão. O caminho é longo, mas o caminhar é contínuo. 


\section{Agradecimentos}

As autoras agradecem ao Colegiado de Letras do Instituto de Educação, Agricultura e Ambiente - IEAA com sede em Humaitá - Amazonas, Brasil, campus da Universidade Federal do Amazonas - UFAM por toda disposição para serem os sujeitos desse estudo. Assim como agradecem ao Programa de Pós-Graduação em Ensino de Ciências e Humanidades PPGECH por todo apoio recebido. Nosso agradecimento especial à Fundação de Amparo à Pesquisa do Estado do Amazonas FAPEAM pelo investimento e incentivo dado a esta pesquisa.

\section{Referências}

Abrahão, M. H. M. B. (2003). Memória, narrativas e pesquisa autobiográfica. Revista História da Educação. ASPHE/FaF/UFPel. 14. 79 - 95. https://www.seer.ufgrs.br/asphe/article/view File/30223/pdf

Alves, E. R. F. (2017). A memória da escravidão em The Longest Memory (1994) e Feeding The Ghosts (1997), de Fred D’Aguiar. Tese (Doutorado em Letras) - Programa de Pós-Graduação em Letras- UNESP.

Ana Cesar. (02 de fevereiro, 2021). Entrevista Narrativa. Humaitá, Amazonas. Entrevista concedida à Leoniza Saraiva Santana.

Andrade, S. S. (2012). A entrevista narrativa ressignificada nas pesquisas educacionais. In: Meyer, D. E., \& Paraíso, M. A. Metodologias de pesquisas póscríticas em educação: Mazza edições.

Andrea del Fuego. (26 de dezembro, 2020). Entrevista Narrativa. Humaitá, Amazonas. Entrevista concedida à Leoniza Saraiva Santana.

Bhabha, H. K. (2013). O local da cultura: Editora UFMG.

Bonicci, T. (2007). Teoria e Crítica Literária Feminista: conceitos e tendências: Eduem.

Carolina Maria de Jesus. (22 de janeiro, 2021). Entrevista Narrativa. Humaitá, Amazonas. Entrevista concedida à Leoniza Saraiva Santana.

Cavalcanti, J., \& Blanchard, M. (Org.). (2014). Histórias no Feminino: a influência das narrativas na construção identitária de mulheres educadoras: Miguilim.

Chartier, R. (1997). Crítica textual e história cultural: o texto e a voz, séculos XVI-XVII. In: Leitura: teoria e prática (pp. 67-75): Mercado Aberto.

Clarice Lispector. (03 de fevereiro, 2021). Entrevista Narrativa. Humaitá, Amazonas. Entrevista concedida à Leoniza Saraiva Santana.

Coelho. N. N. (1993). A literatura feminina no Brasil contemporâneo: Siciliano.

Cosson, R. (2014). Letramento literário: teoria e prática. (2a ed), Contexto.

Costa, M. V. (2007). Introdução. In: Costa, M. V. (Org.). Caminhos Investigativos I: novos olhares na pesquisa em Educação (pp. 13 - 22). (3a ed.): Lamparina.

Del Priore, M. (org.). (2009). História das Mulheres no Brasil. (9a ed.): Contexto.

Emily Brontë. (02 de fevereiro, 2021). Entrevista Narrativa. Humaitá, Amazonas. Entrevista concedida à Leoniza Saraiva Santana.

Falci, M. K. (2009). Mulheres no sertão nordestino. In: Del Priore, Mary (Org.). História das Mulheres no Brasil (pp. 241 - 277). (9. ed.): Contexto.

Florbela Espanca. (25 de janeiro, 2021). Entrevista Narrativa. Humaitá, Amazonas. Entrevista concedida à Leoniza Saraiva Santana.

González Rey, F. (2005). Pesquisa Qualitativa e Subjetividade: os processos de construção da informação. Tradução Silva, M. A. F. Pioneira Thomson Learning.

Hall, S. (2006). A identidade cultural na pós-modernidade. (11a ed.). Tradução Silva, T. T., \& Louro, G. L.: DP\&A.

Halbwachs, M. (2006). A Memória Coletiva. Tradução Sidou, B.: Centauro.

Halbwachs, M. (2013). A Memória Coletiva. Tradução Sidou, B.: Centauro.

IBGE - 2020. Dados sobre Humaitá - AM. https://www.ibge.gov.br/cidades-e-estados/am/humaita.html

IEAA, UFAM. (2016). Memorial histórico: IEAA - 10 anos: EDUA.

IEAA, UFAM. (2019). Projeto Político do Curso de Letras: Língua e Literatura Portuguesa e Língua e Literatura Inglesa: EDUA.

Imbernón, F. (2010). Formação continuada de professores. Tradução Padilha, J. S.: Artmed.

Jane Austen. (02 de fevereiro, 2021). Entrevista Narrativa. Humaitá, Amazonas. Entrevista concedida à Leoniza Saraiva Santana. 
Research, Society and Development, v. 10, n. 7, e46810717111, 2021

(CC BY 4.0) | ISSN 2525-3409 | DOI: http://dx.doi.org/10.33448/rsd-v10i7.17111

Kate Chopin. (2021). Entrevista Narrativa. Humaitá, Amazonas. Entrevista concedida à Leoniza Saraiva Santana.

Larrosa, J. (2011). Tecnologias do eu e educação. In: Silva, T.T. (Org.). O sujeito da educação: estudos foucaultianos (pp. 35 - 86). (8a ed.): Vozes.

Louro, G. L. (Org.). (2018). O corpo educado: pedagogias da sexualidade. (4. ed.). Tradução Silva, T.T.: Autêntica.

Meyer, D. S. \& Paraíso, M. A. (2012). Apresentação: Metodologias de pesquisas pós-críticas ou sobre como fazemos nossas investigações. In: Meyer, D. S.\& Paraíso, M. A. (Orgs.). Metodologias de pesquisas pós-críticas em educação (pp. 15 - 21). Mazza Edições.

Moisés, Massaud. (2004). Dicionário de termos literários. (12. ed.): Cultrix.

Muszkat, M. (1985). A Mulher em Busca de sua Identidade (Introdução). In: Seabra, Z., \& Muszkat, M. Identidade Feminina (pp. 12 - 15): Vozes.

Nóvoa, A. (Coord.). (1992). Os professores e a sua formação. Dom Quixote. http://hdl.handle.net/10451/4758.

Oliveira, K. R. B. (2021). Escola e Memória. Tese de doutorado. UNINOVE.

Silveira, R. M. H. (2007). A Entrevista na pesquisa em educação - uma arena de significados. In: Costa, M.V.(Org.). Caminhos Investigativos II: Outros modos de pensar e fazer pesquisa em educação(pp. 117 - 138). (3a ed.): Lamparina.

Silvestre, M. A. C. (2006). Processos de construção e representação da identidade feminina em contos de Kate Chopin. Tese de Doutorado em Estudos Literários: Universidade Estadual Paulista.

Simson, O. R. M. V. (2003). Memória, cultura e poder na sociedade do esquecimento. Augusto Guzzo Revista Acadêmica. 6: FICS.

Szymanski, H. (Org.). (2018). A entrevista na pesquisa em educação: a prática reflexiva. (5a ed.): Autores Associados.

Simone de Beauvoir. (26 de janeiro, 2021). Entrevista Narrativa. Humaitá, Amazonas. Entrevista concedida à Leoniza Saraiva Santana.

Sylvia Plath. (03 de fevereiro, 2021). Entrevista Narrativa. Humaitá, Amazonas. Entrevista concedida à Leoniza Saraiva Santana.

Tardif, M. (2014). Saberes docentes e formação profissional. (17a ed.): Vozes.

Telles, N. (2009). Escritoras, escritas, escrituras. In: Del Priore, M. (Org.). História das Mulheres no Brasil (pp. 401 - 442 ). (9a ed.): Contexto.

Veiga Neto, A. (2003). Cultura, cultura e a educação. Revista Brasileira de Educação. 23, 5 - 14.

Virginia Woolf. (06 de dezembro, 2020). Entrevista Narrativa. Humaitá, Amazonas. Entrevista concedida à Leoniza Saraiva Santana.

Woodward, K. (2013). Identidade e diferença: uma introdução teórica e conceitual. In: Silva, T.T. (Org.). Identidade e diferença: a perspectiva dos estudos culturais (pp. 7 - 72). (13a ed.): Vozes.

Zolin, L. O. Crítica Feminista. (2003). In: Bonnici, T., \& Zolin, L. O. Teoria Literária: Abordagens históricas e tendências contemporâneas (pp. 161 - 182): Eduem. 